\title{
誘導結合高周波プラズマ発光分光分析法による 各種試料中のリンの定量
}

\author{
河口公司，伊藤 哲雅，水池政*
}

(1977 年 9 月 5 日受理)

誘導結合高周波プラズマ (ICP) を光源とする発光分光分析法でリンを定量するときの最適条件を見 いだし，金属試料，食品などの中のリンの定量を行った。スペクトル線はPI $213.62 \mathrm{~nm}$ が最適で高周 波電力の増加とともに発光強度は大きくなるが, バックグラウンド強度も増加する. 本研究では $1.2 \mathrm{~kW}$ で使用した、ナトリウム，マグネシウム，カルシウムなどの共存は（1〜5) $\mathrm{mg} / \mathrm{ml}$ まで影響がなく，それ 以上ではスペクトル線強度が低下した. 酸の影響についても同様で, 試料の粘性の増加につれて強度が 低下した。ガス流量の変化はスペクトル線強度には大きな影響を与兄なかった。検量線は（0.5〜 5000) $\mu \mathrm{g} / \mathrm{ml}$ まで直線であった。リン $10 \mu \mathrm{g} / \mathrm{ml}$ でのスペクトル線強度の相対標準偏差は $0.95 \%$ であった。 実際試料として鉄鋼, リン青銅, ミルク,でえ粉, ビール, 土じょうなどの中のリンの定量を行った が，スペクトル線の妨害のある鉄鋼以外は満足な結果が得られた。

\section{1 綃菑}

誘導結合高凨波プラズマ(ICP) を光源とする溶液試 料の発光分光分析は，高感度で，精度も原子吸光法と同 程度で分析でき，叉ダイナミックレンジも（3～5）けた と大きく，其得元素の影響を受けにくいなど，多元素を 同時定量するのに傎れた特徽を持っていることが報告さ

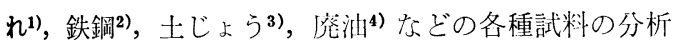
に利用されている。

リンは岩石，土じょう，動植物など広く自然界に分布 し，又金属材料の性質にも大きな影響を与えることが知 られている.リンの定量には一般に吸光光度法が用いら れ，原子吸光法で直接定量したことも報告されている5) が, 前者は操作が煩雑で妨害が多く, 後者も感度はあま りよくないＩCP によるリンの発光分光分析法は比較 的高感度であることが知られているが，各種試料中のリ ンの定量について都細に検討した論文は見当たらないよ うである。そこで著者らは，ICPでりンを定量する際の 高周波電力, ガス流量, 共存元素などの影響を調べ, 最 適条件を求めた。更に実際試料として，鉄鋼，リン青銅， 食品，土じょう中のリンの定量を試みたので，その結果 を報告する。

$$
2 \text { 装紧 }
$$

Table 1 亿使用した主な装置及び操作条件を示す。日

* 名古屋大学工学部: 愛知県名古屋市千種区不老町
Table 1 Instruments and operating conditions

\begin{tabular}{|c|c|}
\hline Spectrometer & $\begin{array}{l}\text { Shimadzu GE-100, Ebert mounting, grating: } \\
1200 \text { lines } / \mathrm{mm}, 0.83 \mathrm{~nm} / \mathrm{mm} \text {, photomultiplier : } \\
\text { HTV, R-106, slit : entrance } 50 \mu \mathrm{m} \text {, exit } 70 \mu \mathrm{m}\end{array}$ \\
\hline Amplifier & NF, Lock-in Amp, LI-572B, time constant $: 3 \mathrm{~s}$ \\
\hline Recorder & Shimadzu, U-125 MN \\
\hline ICP source & $\begin{array}{l}\text { Nippon Koshuha, } 27.12 \mathrm{MHz} \text {, max. : } 2 \mathrm{~kW}, \\
\text { output power : } 1.2 \mathrm{~kW} \text {, reflected power }:< \\
\text { low }\end{array}$ \\
\hline Ar flow & $\begin{array}{l}\text { Coolant : } 10 \mathrm{l} / \mathrm{min} \text {, plasma }: 1.4 \mathrm{l} / \mathrm{min} \text {, carrier : } \\
0.8 \mathrm{l} / \mathrm{min} \text {. }\end{array}$ \\
\hline
\end{tabular}

本高周波(株) に依頼して試作した ICP 電源は, 発振周 波数 $27.12 \mathrm{MHz}$ の水晶発振方式で, 発振一励振一電力増 幅の 3 段構成で，電力増幅管には 7F 37R（プレート損 失 $1 \mathrm{~kW})$ を使用している. 高周波電力の制御は電力増 幅管のスクリーン電圧を变化させることにより行った。 従って, スクリーン電源は可変型の安定化電源となって いる. 又, 電力增幅管のプレート電源は 3 相ブリッジ整 流で得た $4.5 \mathrm{kV}$ の電圧で, リップルフィルタ一を通し て供給されている.電力增幅された高周波は, 通過型電 力計を通って $50 \Omega$ のインピーダンスで出力され，マッ チング回路及び 2 ターンの誘導コイルを通して放電管に 結合されている．通過型電力計で進行波電力及び反射波 電力を直読できるようにした。

放電管は石英管の交換が容易なように, Fig. 1 に示し たように組み立て式の 3 重管構造とした。 $50 \mathrm{~mm} \phi \times 50$ $\mathrm{mm}$ のテフロンブロックに石英管を入れる穴をあけ，石 英管をエポキシ系接着㓮で固定する。このとき，管は軸 対称になっていないとプラズマの刘称性が悪くなり，石 英管の先端部が溶融して変形する可能性があるので， べ ークライトの棒を階段状に加工して作った治具で石英管 


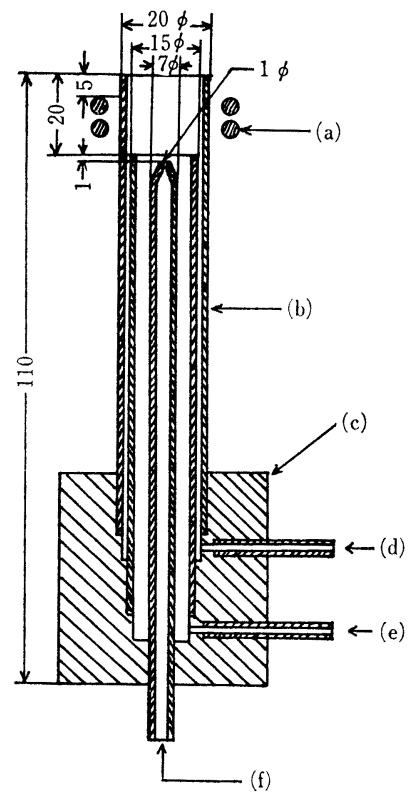

Fig. 1 Plasma tube

(a) RF coil; (b) Quartz; (c ) Teflon; (d) Coolant gas inlet, $2 \phi, 101 / \mathrm{min}$; (e) Plasma gas inlet, $2 \phi$, $1.41 / \mathrm{min}$; (f) Aerosol inlet

を固定して接着剂を固化させた。テフロンへの接着用の 接着性はよくないが，通常の使用条件では十分であり， 石英管の交換も容易である。塩濃度の濃い溶液を分析す ると，使用につれて試料導入管（中心の石英管）の内部 が污れてくるので, 取り外して洗浄するか, 交換する必 要がある. 試料導入管の先端の内径はプラズマの形状の 再現性を得るために重要である.

ネブライザーは島津製作所製のガラス同軸型噴霧器及 びスプレーチェンバーを使用した。キャリヤーガス流量 $0.8 \mathrm{l} / \mathrm{min}$ のとき試料吸い上げ量は $2.9 \mathrm{ml} / \mathrm{min}$ でプラ ズマへの試料導入効率は約 $3.4 \%$ であった. 分光器への 集光系は中間結像法を使用した。

\section{3 実験結果及び考察}

\section{1 スペクトル線}

リンの強度の大きいスペクトル線は真空紫外部 (177.5, $178.3 ， 178.8 \mathrm{~nm})$ にあるが，今回の測定では紫外部の スペクトル線 $(213.62,214.91 ， 253.57 \mathrm{~nm})$ について 検討した・各スペクトル線のプラズマ内での高さ方向の 強度分布は Fig. 2 のようになった. Fig. 2 にはバック グラウンド強度の分布も示してある.どのスペクトル線 もコイルに近い低い位置ほど強度が増加している。PI $213.62 \mathrm{~nm}$ の線は，コイルから $5 \mathrm{~mm}$ 付近では他のスヘ クトル線に比較して強度も強く, バックグラウンドも低 いのでリンのみを定量するのには最も適している．他の

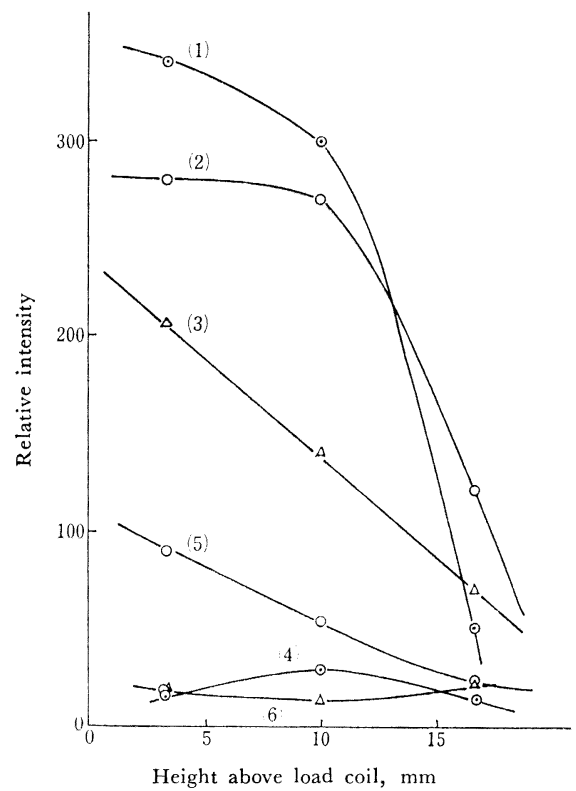

Fig. 2 Vertical distribution of intensity

$\mathrm{P}: 10 \mu \mathrm{g} / \mathrm{ml}$; (1) $213.62 \mathrm{~nm}$; (2) $253.57 \mathrm{nm;} \mathrm{(3)}$ $214.91 \mathrm{~nm}$; (4), (5), (6) Background for each line

元素ではコイルから $(15 〜 20) \mathrm{mm}$ 上方で最高強度を示 すものが多く，多元素同時定量ではこの領域を用いるの が一般的であるので，他の元素と同時に定量をする場合 にはPI 253.65nm の涪うが適していると思われる. 本 実験ではりンのみを定量したので，分析線の重なりによ る妨害（CuII $213.60 \mathrm{~nm}$ など）がない限り PI 213.62 $\mathrm{nm}$ を使用した。

\section{2 高周波電力の影響}

Fig. 3 は PI 213.62nm で高同波電力を変化したとき のスペクトル線強度の変化を示したものである. コイル から $10 \mathrm{~mm}, 17 \mathrm{~mm}$ の位置では, 強度は高周波電力の 增加とともに直線的に増加するが， $3 \mathrm{~mm}$ の位置では高 周波電力の变化に対して強度の变化が緩やかになってい る. 高周波電力を增すと強度も增すが，それにつれてバ ッグラウンドの強度も增し, 必ずしも検出下限を下げる ことにはならない. 本実験では $1.2 \mathrm{~kW} て ゙$ て使用した。

バックグラウンドは主としてアルゴンの再結合に基づ く連続スペクトルによるもので，分子スパクトル性のバ ックグラウンドは比較的少ない.

\section{3 ガス流量の影響}

冷却ガス流量 $\{(8 \sim 13) 1 / \min \}$ 及びキャリヤーガス流 量 $\{(0.5 \sim 0.8) 1 / \mathrm{min}\}$ の変化に対するスペクトル線強 


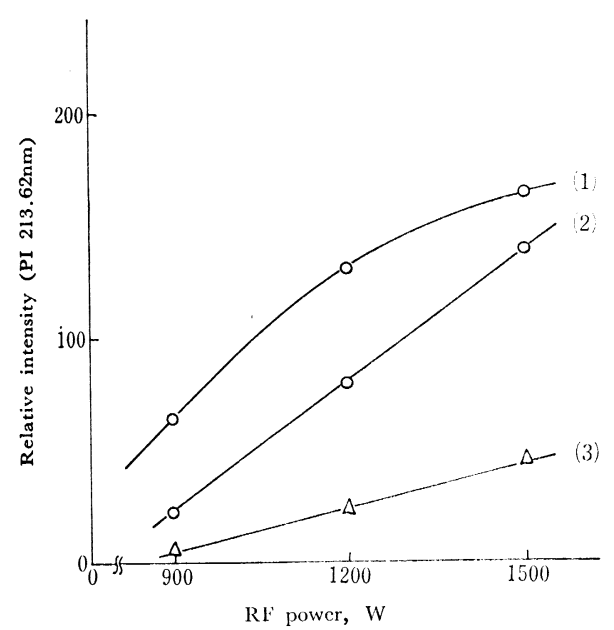

Fig. 3 Variation of intensity as a function of $\mathrm{RF}$ power

Height above coil : (1) $3 \mathrm{~mm}$, ( 2 ) $10 \mathrm{~mm}$, ( 3 ) $17 \mathrm{~mm}$

度及びバックグラウンドの変化はそれほど大きくない。 冷却ガスの流量を変えると,プラズマの形状が変化する. 流量が少なくなるとプラズマが短く太くなり，放電管が 赤熱するようになるので, 高周波電力によって领却ガス は一定流量より大きくする必要がある，高周波電力 1.2 $\mathrm{kW}$ のときは $10 \mathrm{l} / \mathrm{min}$ で十分であった.

キャリヤーガスはネブライザーからの試料の霧を含ん でいるが，その流量が少なくなるとプラズマ内の試料の 滞留時間が長くなり，スペクトル線強度を増すように作 用するが，同時に試料導入量が減少するので，結局キャ リャーガスの流量に対して大きなスペクトル線強度の変 化がないものと考光られる.このことは超音波ネブライ ザーを用いたときは，キャリヤーガス流量によってスペ クトル線強度が大きく変化することからも確かめられる が，この点については更に検討中である.

プラズマガス流量はほとえど強度に影響を与えない。 プラズマガスを全く流さなくてもよいという報告6）も多 いが，中間の石英管の破損を少なくするためプラズマを わずかに浮かせるのに必要な量を流すのがよく，本実験 では $1.41 / \mathrm{min}$ とした。

\section{4 共存物質の影響}

リンの濃度 $10 \mu \mathrm{g} / \mathrm{ml}$ の溶液に硝酸, 酡酸, 硫酸, ク エン酸を $10 \mathrm{wt} \%$ 前後まで步存させたときの PI 213.62 nm のスペクトル線強度の変化を Fig. 4 に示す. 硫酸, クエン酸では約 $0.06 \mathrm{wt} \%$ 方ら負の影響を受ける.塩酸 では $3 \mathrm{wt} \%$ まで，硝酸では $10 \mathrm{wt} \%$ 近くまでほとんど

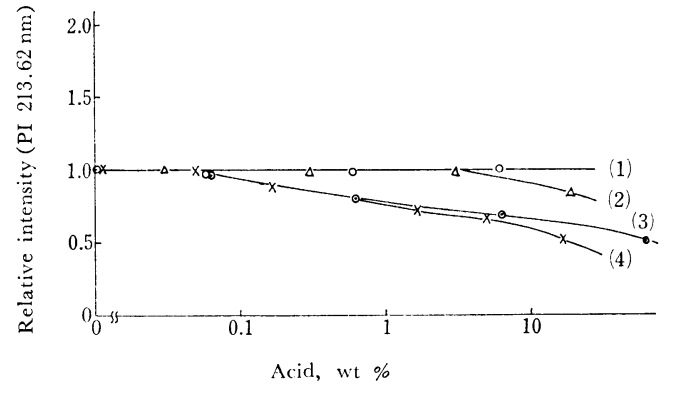

Fig. 4 Effect of acidity on $\mathrm{P}$ emission intensity $\mathrm{P}: 10 \mu \mathrm{g} / \mathrm{ml} ;$ ( 1 ) $\mathrm{HNO}_{3} ;$ (2) $\mathrm{HCl}$; (3) $\mathrm{H}_{2} \mathrm{SO}_{4}$, (4) Citric acid

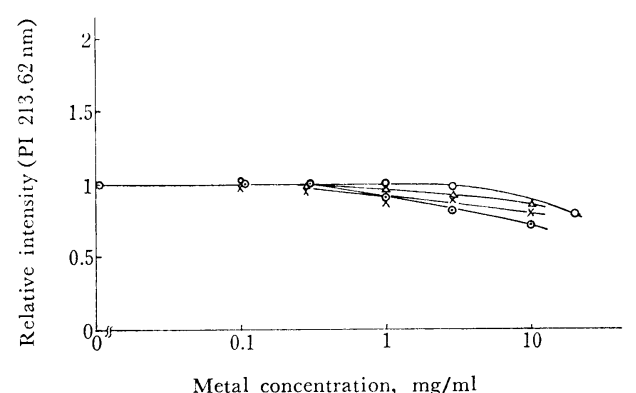

Fig. 5 Effect of various elements on $\mathrm{P}$ emission intensity

$-\triangle-\mathrm{Fe}(\mathrm{P} 100 \mu \mathrm{g} / \mathrm{ml}) ; \quad-\mathrm{O}-\mathrm{Na}(\mathrm{P} 10 \mu \mathrm{g} / \mathrm{ml})$; $-\times-\mathrm{Mg}(\mathrm{P} 10 \mu \mathrm{g} / \mathrm{ml}) ; \quad-O-\mathrm{Ca}(\mathrm{P} 10 \mu \mathrm{g} / \mathrm{ml})$

影響を受けなかった。

Fig. 5 は鉄，ナトリウム，マグネシウム，カルシウム をそれぞれ共存させたときの PI $213.62 \mathrm{~nm}$ のスペクト ル線強度に及ぼす影響を示したものである。これらの元 素はそれぞれ塩化物の水溶液を用いた、リンの濃度は鉄 の場合だけ $100 \mu \mathrm{g} / \mathrm{ml}$ とし, 他の元素に対しては $10 \mu \mathrm{g} /$ $\mathrm{ml}$ とした. ぞの元素もほぼ同様の挙動を示し，(1〜数） $\mathrm{mg} / \mathrm{ml}$ 以上になるとスペクトル線強度が低下しはじめ る.カルシウム及びマグネシウムの場合は， $1 \mathrm{mg} / \mathrm{ml}$ 上の濃度でバックグラウンドが増加しはじめるので，そ の補正をする必要がある。これらの元素の強いスペクト ル線が分光器内の散乱によって検出器に入ってくるもの と考光られる7)，Fig. 5 では，バックグラウンド強度を 差し引いたものをプロットしてある.

鉄が多量に共存すると，鉄の弱いスペクトル線 $\mathrm{Fe}$ $213.60 \mathrm{~nm}$ が妨害する。この線の強度は鉄 $10 \mathrm{mg} / \mathrm{ml} の$ とき，リンの $12 \mu \mathrm{g} / \mathrm{ml}$ に相当することが分かった．鉄 の多い試料では分離をしておく必要がある.

酸の濃度が高くなったときスペクトル線の強度が減 
少するのは，主に試料溶液の粘性が大きくなり，ネブ ライザーの 試料導入効率が低下するためであることを Greenfield ら8) が報告しているが，Fig. 4 の結果はかれ らの結果とほとえど一致しており，同様の影響によるも のと考元られる. 又 Fig. 5 の共存元素の影響について も, 各元素とも同様の影響を与えることから, 試料導入 効率に対する影響が主なものであると思われる.

銅は Cu 213.60nm 唯強く妨害するので，PI 253.56 $\mathrm{nm}$ に対する影響を調べたが，この線は銅 $10 \mathrm{mg} / \mathrm{ml}$ ま で影響を受けなかった。

\section{5 検量線及び再現性}

リン酸二水素カリウム水溶液を用いて作ったりンの検 量線は，両対数グラフ上で $(0.5 \sim 5000) \mu \mathrm{g} / \mathrm{ml}$ の範囲で $45^{\circ}$ の直線となり，4けたのダイナミックレンジが得ら れた. $5000 \mu \mathrm{g} / \mathrm{ml}$ より高濃度では $45^{\circ}$ の直線からしだ いに下側へ離れていった。 これは, 試料溶液の粘度の増 加のため試料導入量が変化することによるものと考兄ら れる。

リン濃度 $10 \mu \mathrm{g} / \mathrm{ml}$ の溶液を 13 回繰り返し測定した 結果，スペクトル線強度の相対標準偏差は $0.95 \%$ であ った．検出下限をバックグラウンド強度の变動の 2 倍の 強度を示すリン濃度と定義すると，PI $213.62 \mathrm{~nm}$ を使 ったときの検出下限は $0.12 \mu \mathrm{g} / \mathrm{ml}$ であり, PI 253.56 $\mathrm{nm}$ では $1.9 \mu \mathrm{g} / \mathrm{ml}$ であった。

\section{4 実際試料の分析}

鉄鋼試料 : 日本鉄鋼協会鉄鋼標準試料 JSS-030, JSS -023, JSS-168, JSS-170 それぞれ $1 \mathrm{~g}$ に $(1+1)$ 塩酸 $30 \mathrm{ml}$ と硝酸 $5 \mathrm{ml}$ を加光加熱溶解後蒸発乾固し, 塩酸 $10 \mathrm{ml}$ で塩を溶解して水で $200 \mathrm{ml}$ に希釈した. これに より鉄鋼中のリン $(40$ 200) ppm の検量線を作成した が，Fe $213.60 \mathrm{~nm}$ の妨害が鉄中のリン濃度に換算して $1200 \mathrm{ppm}$ となり, 鉄を分離するか, より高分解能の分 光器を用いないと鉄鋼中の微量リンの正確な定量は不可 能であることが分かった.リンの他のスペクトル線に対 しても鉄のスペクトル線の強い妨害がある.

リン青銅 : リン青銅約 $250 \mathrm{mg}$ を希硝酸で洗浄後, 正 確にひょう量し, $(1+1)$ 塭酸 $10 \mathrm{ml}$ と硝酸 $1.3 \mathrm{ml}$ を 加光加熱溶解し, 蒸発乾固させ, 生じた塩を塩酸 $2.5 \mathrm{ml}$ で溶解し，水を加え $50 \mathrm{ml}$ とした。分析線は PI 253.56 $\mathrm{nm}$ を使用した・検量線による測定結果と ICP による 標準添加法による分析の結果とを Table 2 に示与.

食品の分析：でえ粉，インスタントコーヒ一，乳児用 粉ミルク，牛乳及びビールの分析を行った．でえ粉は少
Table 2 Determination of phosphorus in various samples

\begin{tabular}{|c|c|c|c|}
\hline \multirow{2}{*}{ Sample } & \multicolumn{2}{|l|}{ ICP } & \multirow{2}{*}{$\begin{array}{c}\text { Spectrophotometric } \\
\text { P }(\%)\end{array}$} \\
\hline & Solution & $P(\%)$ & \\
\hline Phosphor bronze & 0.5 wt. $\%$ in dil. $\mathrm{HCl}$ & 0.19 & $0.18 \dagger$ \\
\hline Starch & 1 wt. $\%$ in dil. $\mathrm{HCl}$ & 0.046 & 0.036 \\
\hline Instant coffee & 1 wt. $\%$ in $\mathrm{H}_{2} \mathrm{O}$ & 0.33 & 0.34 \\
\hline Soft curd milk & 1 wt. $\%$ in $\mathrm{H}_{2} \mathrm{O}$ & 0.35 & 0.35 \\
\hline Milk & 10 vol. $\%$ in $\mathrm{H}_{2} \mathrm{O}$ & 0.074 & 0.079 \\
\hline Beer & 10 vol. $\%$ in $\mathrm{H}_{2} \mathrm{O}$ & 0.018 & 0.019 \\
\hline \multirow[t]{2}{*}{ Soil } & extracted with & & \\
\hline & $\begin{array}{c}0.002 \mathrm{~N} \mathrm{H}_{2} \mathrm{SO}_{4} \\
(5 \mathrm{~g} \text { soil } / 50 \mathrm{ml})\end{array}$ & 0.045 & $0.045 \dagger$ \\
\hline
\end{tabular}

量の熄酸を加え加熱分解し，1 wt $/ \%$ の溶液に希釈した。 他のものは, 単に水で希勫しただけでプラズマに噴霧し た. 希釈条件及び分析結果を Table 2 に示す. Table 2 には，湿式灰化一モりブデンブルー吸光光度法9）による 分析結果も示したが, 両者の結果はよく一致している. 牛乳について, 希䣋度とリンのスペクトル線強度との関 係を両対数グラフにプロットした結果，10\%以下に希釈 したものは $45^{\circ}$ の直線となったが，それ以上では直線よ り下に外れた。これは主として牛乳の粘性が增大し試料 の導入効染が低下することによるものと思われる.

土じょう中の可溶性リン: 畑の地表面の土をサンプル として風乾させ, その $5 \mathrm{~g}$ に $0.002 \mathrm{~N}$ 硫酸 $50 \mathrm{ml}$ を加 え, 30 分間振とう後沪過し, 沪液をプラズマに噴霧し た. 又沪液を $1 / 10 ， 1 / 2 ， 1 / 1$ にそれぞれ希釈して測定 した結果を希釈度に対してグラフにプロットした結果, 原点を通る直線となった。 Table 2 には，IGPによる標 準添加法による分析値も示した.

本報では装置の関係から単元素分析となったが, 多元 素同時定量を行う場合には, 多くの利点が得られると考 光らる。

試料導入法に関しては，本实験で使用したような噴霧 器の外に, 超音波ネブライザーなど各種の方法が既に報 告されているが，更に今後の検討が必要であると思われ る.

\section{交献}

1) V. A. Fassel, R. N. Kniseley : Anal. Chem., 46, 1110A (1974).

2) C. C. Butler, R. N. Kniseley, V. A. Fassel : ibid., 47, 825 (1975).

3) R. H. Scott, M. L. Kokot : Anal. Chim. Acta, 75, 257 (1975).

4) V. A. Fassel, C. A. Peterson, F. N. Abercrombie, R. N. Kniseley : Anal. Chem., 48, 516 (1976). 
5) G. F. Kirkbright, M. Marshall : ibid., 45, 1610 (1973).

6) P. W. J. M. Boumans, F. J. de Boer : Spectrochim. Acta, 30B, 309 (1975).

7) G. F. Larson, V. A. Fassel, R. K. Winge, R. N. Kniseley : Appl. Spectry., 30, 384 (1976).

8) S. Greenfield, H. McD. McGeachin, P. B. Smith: Anal. Chim. Acta, 84, 67 (1976).

9) 平野四蔵編 : “無機応用比色分析”, 4, p. 189 (1975)，（共立出版).

$$
\hat{s}
$$

Determination of phosphorus in various samples by inductively coupled plasma-optical emission spectrometry. Hiroshi KawaGuchi, Tetsumasa ITo and Atsushi Mrzurke (Faculty of Engineering, Nagoya University, Furo-cho, Chikusa-ku, Nagoya-shi, Aichi)

A crystal-controlled, $27.12 \mathrm{MHz}$ radio-frequency generator ( $2 \mathrm{~kW}$ max.) was employed to induce a plasma in a torch tube which was assembled on a Teflon base in such a way that 3 separate quartz tubes were easily replaced. A grating monochromator $(1 \mathrm{~m}$, Ebert mounting, $0.83 \mathrm{~nm} / \mathrm{mm}$ ) was used to measure phosphorus lines $(213.62,214.91$ and $253.57 \mathrm{~nm})$, the first line being most sensitive. At the RF power of $1.2 \mathrm{~kW}$, argon flow rates were regulated at $101 / \mathrm{min}$ for coolant gas, 1.4 for plasma gas, and 0.8 for carrier gas. The analytical curve for phosphorus was linear over the range of $(0.5 \sim 5000) \mu \mathrm{g} / \mathrm{ml}$. Sodium, calcium and magnesium did not affect the intensity of phosphorus line up to (1 5) $\mathrm{mg} / \mathrm{ml}$. Suppression of the intensity by higher concentrations of these elements was considered to be due to the decrease of sample introduction rate. Detection limits of phosphorus were 0.12 and $1.9 \mu \mathrm{g} / \mathrm{ml}$ depending on the lines, 213.62 and $253.56 \mathrm{~nm}$, respectively. Phosphor bronze, milk, starch, beer, soil, etc. were successfully analyzed for phosphorus with minimum pretreatment. Trace amounts of phosphorus in steel could not be determined accurately without separation of iron because of the spectral interference of $\mathrm{Fe} 213.6 \mathrm{~nm}$.

(Received Sept. 5, 1977)

\section{Keywords}

Emission spectrometry

Inductively coupled plasma

Phosphorus 